\title{
Citrobacter youngae
}

National Cancer Institute

\section{Source}

National Cancer Institute. Citrobacter youngae. NCI Thesaurus. Code C86268.

A species of facultatively anaerobic, gram negative, rod shaped bacteria assigned to the phylum Proteobacteria. This species is motile by peritrichous flagella, indole negative, ornithine decarboxylase negative and produces acid from dulcitol but not melibiose. C. youngae is a commensal org anism of the gastrointestinal tract and may cause nosocomial infections. 